\title{
Autocrine, Not Paracrine, Interferon-Gamma Gene Delivery Enhances Ex Vivo Antigen-Specific Cytotoxic T Lymphocyte Stimulation and Killing
}

\author{
Dazhi Zhang, ${ }^{1,2}$ Yong Liu, ${ }^{3}$ Min Shi, ${ }^{1,4}$ Chang Xuan You, ${ }^{1,4}$ Maohua Cao, ${ }^{1}$ Rong Cheng Luo, ${ }^{4}$ \\ and Paul L. Hermonat ${ }^{1,3,5}$ \\ ${ }^{1}$ Department of Internal Medicine, University of Arkansas for Medical Sciences, Little Rock, AR 72205, USA \\ ${ }^{2}$ Research and Therapy Center for Hepatic Diseases, The 2nd Affiliated Hospital, The 2nd Medical College, \\ Chongqing Medical University, Chongqing 630046, China \\ ${ }^{3}$ Department of Obstetrics and Gynecology, University of Arkansas for Medical Sciences, Little Rock, AR 72205, USA \\ ${ }^{4}$ Department of Oncology, Nanfang Hospital, Southern Medical University, Guangzhou 510515, China \\ ${ }^{5}$ Central Arkansas Veterans Healthcare System, 111J, 4300 West 7th Street, Little Rock, AR 72205, USA
}

Correspondence should be addressed to Paul L. Hermonat, plhermonat@uams.edu

Received 30 November 2009; Accepted 24 February 2010

Academic Editor: Hanchun Yang

Copyright ( 2010 Dazhi Zhang et al. This is an open access article distributed under the Creative Commons Attribution License, which permits unrestricted use, distribution, and reproduction in any medium, provided the original work is properly cited.

\begin{abstract}
The adoptive transfer of antigen-specific cytotoxic T lymphocytes (CTL) shows promise in the treatment of cancer and infectious diseases. We utilize adeno-associated virus-(AAV-) based antigen gene-loaded dendritic cells (DCs) to stimulate such antigenspecific CTL. Yet further improvements in CTL stimulation and killing may result by gene delivery of various Th1-response interferons/cytokines, such as interferon $\gamma$ (IFN- $\gamma$ ), as the delivered gene can continuously produce that interferon. However which immune cell type should optimally express IFN- $\gamma$ is unclear as the phenotypes of both DC and T cells are enhanced by it. Here, we used AAV to compare and contrast IFN- $\gamma$ gene delivery into DC or T cells, and versus the addition of exogenous IFN- $\gamma$, for stimulating carcinoembryonic antigen-(CEA-) specific CTL. It was found that AAV/IFN- $\gamma$ delivery into T cells (autocrine) resulted in T cell populations with the highest CD8(+)/CD4(+) ratio, highest IFN- $\gamma(+) / \mathrm{IL}-4(+)$ ratio, highest CD69(+),CD8(+) levels, and lowest CD4(+)/CD25(+) levels, all consistent with the strongest Th1 response. Most importantly, AAV/IFN- $\gamma$ transduction of T cells resulted in antigen-specific $\mathrm{T}$ cell populations with the highest killing capabilities, $49 \%$ above other treatments. These data strongly suggest that AAV/IFN- $\gamma$ autocrine gene delivery into T cells is worthy of further study towards maximizing the generation of antigen-specific anticancer CTL killers.
\end{abstract}

\section{Introduction}

Adoptive immunotherapy, particularly adoptive transfer of antigen-specific cytotoxic T lymphocytes, has shown some success in clinical trials for treating both cancer and viral infections [1-5]. However, due to resident tolerance within the tumor environment the most robust CTL must be stimulated for highest efficacy. Delivery of antigen genes into dendritic cells (DCs) or precursor monocytes (Mo) allows for the stimulation of robust antigen-specific CTL [6]. However, there are a variety of improvements that might be made to further enhance CTL stimulation. One obvious course is the delivery of Th1-response interferons/cytokine genes into immune cells for their continuous expression.

Interferon gamma (IFN- $\gamma$ ) is an important Th1 response interferon/cytokine involved in CTL generation and function and might be used to enhance CTL stimulation. IFN- $\gamma$ likely has multiple mechanisms of action [7-10]. It is believed to inhibit expression of the IL-4 receptor. This is important as IL-4 correlates with low and ineffective CTL activity. In addition, IFN- $\gamma$ may have other non-T cell-associated attributes as it is believed to stimulate expression of HLA Class I and II molecules. However, overall IFN- $\gamma$ is strongly linked to the induction of Th1 response, the generation of 
CTL. Of all the Th1 response interferons/cytokines IFN- $\gamma$ correlates most strongly with the Th1 response [9-11] as, in fact, many laboratories study $\mathrm{T}$ cell expression of IFN$\gamma$ as a substitute for carrying out CTL killing/chromium release assays $[12,13]$. Moreover, IFN- $\gamma$ plus IL-12 appears to act cooperatively in the generation of a very strong Th1 response $[14,15]$. IFN- $\gamma$ may also partially overcome low activation and expansion rates of low-avidity CTL $[16,17]$. As with most of the Th1-response-associated chemokines, IFN- $\gamma$ is associated with regulation of perforin/Granzyme B [18]. Thus, gene delivery of IFN- $\gamma$ will likely be very useful in generating a robust Th1 CTL response.

While IFN- $\gamma$ gene delivery would seem to be beneficial for generating robust CTL, it is unclear which cells should specifically express this cytokine for maximum CTL stimulation. While activated $\mathrm{T}$ cells naturally express IFN$\gamma$, it has been shown that IFN- $\gamma$ is able to significantly affect DC maturity and function as well as DC precursor Mo and macrophage $(M \Phi)$ phenotypes [19-21]. Thus it is unclear which immune cell type should express this cytokine during the initial stimulation of the CD8+ CTL. Two general approaches are available, transducing the DC (paracrine delivery) which stimulate the responder $\mathrm{T}$ cells, or the $\mathrm{T}$ cell themselves (autocrine delivery). Here we demonstrate that IFN- $\gamma$ autocrine gene delivery resulted in significantly higher CEA-specific CTL killing compared with paracrine delivery or exogenous IFN- $\gamma$.

\section{Materials and Methods}

2.1. Cells. The SW480 colorectal adenocarcinoma cell line was obtained from The American Tissue Culture Collection (ATCC). A carcinoembryonic antigen- (CEA-) positive lymphoblastoid cell line (CEA+ LCL) was generated by transfecting an HLA-A2 positive LCL cell line with a CEA plus Neomycin resistance gene (Neo) expression plasmid and selection with $1 \mathrm{mg} / \mathrm{mL}$ G418 for two weeks. Peripheral blood mononuclear cells (PBMCs) from five HLA-A2 positive healthy donors were separated by routine Ficoll gradient method. All blood donors gave informed consent in writing, and the study protocol conformed to the ethical guidelines of the 1975 Declaration of Helsinki as reflected in a priori approval by our Human Research Internal Review Board. The HLA haplotype of all donors was compatible with SW480 cells (HLA A2) and other cells used as controls.

2.2. Construction of Recombinant AAV Vectors. Human CEA and IFN- $\gamma$ cDNAs were amplified by reverse-transcription polymerase chain reaction (RT-PCR). Trizol reagent (Invitrogen) was employed to isolate total RNA from SW480 cells and PHA-stimulated primary human T lymphocytes, respectively. Subsequently, the total mRNA was separate from the total RNA using Oligotex mRNA isolation kit (Qiagen). After the first-strand cDNA was generated, PCR amplification for each of the CDNA was carried out using the following primer pair: CEA: $5^{\prime}$-ACCATGGAGTCTCCCTCG- $3^{\prime}$ and $5^{\prime}$-CTATATCAGAGCAACCCC- $3^{\prime}$ that amplify the sequence from nucleotides 112 to 2223 [22]; IFN- $\gamma: 5^{\prime}$ TTCTCTCGGAAACGATG- $3^{\prime}$ and 5'-GGCAGGACAACCATTAC-3' that amplify the sequence from nt 94 to 622 [23]. All cDNAs were sequenced and determined to be identical to the published sequence. CEA and IFN- $\gamma$ cDNA were inserted in the downstream of $\mathrm{p} 5$ promoter of an $\mathrm{AAV}$ vector, respectively, as described previously [24].

2.3. Transduction of DC by Recombinant AAV. The experimental scheme is shown in Figure 1. The rAAVs were generated, purified, and tittered as described previously [24, 25]. Titer is given as encapsidated genomes (eg) per mL. After freshly isolated PBMCs $\left(5 \times 10^{6}\right)$ were cultured for two hours in AIM-V medium, the nonadherent cells were removed. The remaining adherent Mos were infected immediately with $1 \times 10^{9}$ encapsidated genomes $(\mathrm{eg}) / \mathrm{mL}$ of AAV/CEA virus or AAV/CEA plus AAV/IFN- $\gamma$ virus. After four hours the medium/virus solution was removed and the cells were finally fed with the medium containing recombinant human GM-CSF (Immunex, $800 \mathrm{IU} / \mathrm{mL}$ ). At day 2, to induce the maturation of Mo into DC, recombinant human IL-4 and TNF- $\alpha$ (R \& D SYSTEMS.) were added to the medium at $1000 \mathrm{IU} / \mathrm{mL}$ and $20 \mathrm{ng} / \mathrm{mL}$, respectively. The medium and cytokines were replaced every two days. Finally, at day 6 the DCs were mixed with CD3+ T cells.

2.4. Transduction of CD3+ T Cells by Recombinant $r A A V$. $T$ cells were transduced as described previously [25]. Briefly, Pan T Cell Isolation Kit II (Miltenyi Biotec) was employed to isolate $\mathrm{CD} 3+\mathrm{T}$ cells from the nonadherent cells from the PBMC according to the kit instruction. At day 5 the $\mathrm{CD} 3+\mathrm{T}$ cells $\left(1 \times 10^{6}\right)$ were infected with $1 \times 10^{9} \mathrm{eg} / \mathrm{mL}$ of AAV/IFN- $\gamma$ virus and cultured with $20 \mathrm{ng} / \mathrm{mL}$ of IL-2.

2.5. Analysis of $r A A V$ Chromosomal Integration. The total DNAs were isolated from the $\mathrm{rAAV}$-infected or uninfected DC or T cells using DNAzol reagent (Invitrogen) according to supplier's protocol. Chromosomal integration of the AAV/CEA genome was studied by vector-chromosome junction PCR amplification and southern blot analysis, as previously described [24].

2.6. RT-PCR Expression Analysis of Transduced DC or $T$ Cells for CEA and IFN- $\gamma$ Expression. At day 4 of Mo/DC culture and DC-T cell culture, isolation and amplification of the mRNA was done as described above, respectively. Subsequently, the CEA and IFN- $\gamma$ cDNAs were amplified as described above. TFIIB was amplified as a housekeeping control at the same time. PCR amplification for the TFIIB cDNA was performed using the primer pair: $5^{\prime}$-TGTCTGTTGTGTCTTGTTGC- $3^{\prime}$ and $5^{\prime}$-TAGGCTATGTACAACAGGC-3' that amplify the sequence from nt 319 to 1310 [26].

2.7. Analysis of Transduction and Expression of CEA Antigen and Cytokines by Intracellular Staining. At day 6 of Mo/DC culture and day 4 of rAAV infection of CD3+ T cells, intracellular staining assay was employed, similar to Pala et al. [27]. Briefly, cells were incubated with the FITC- or 


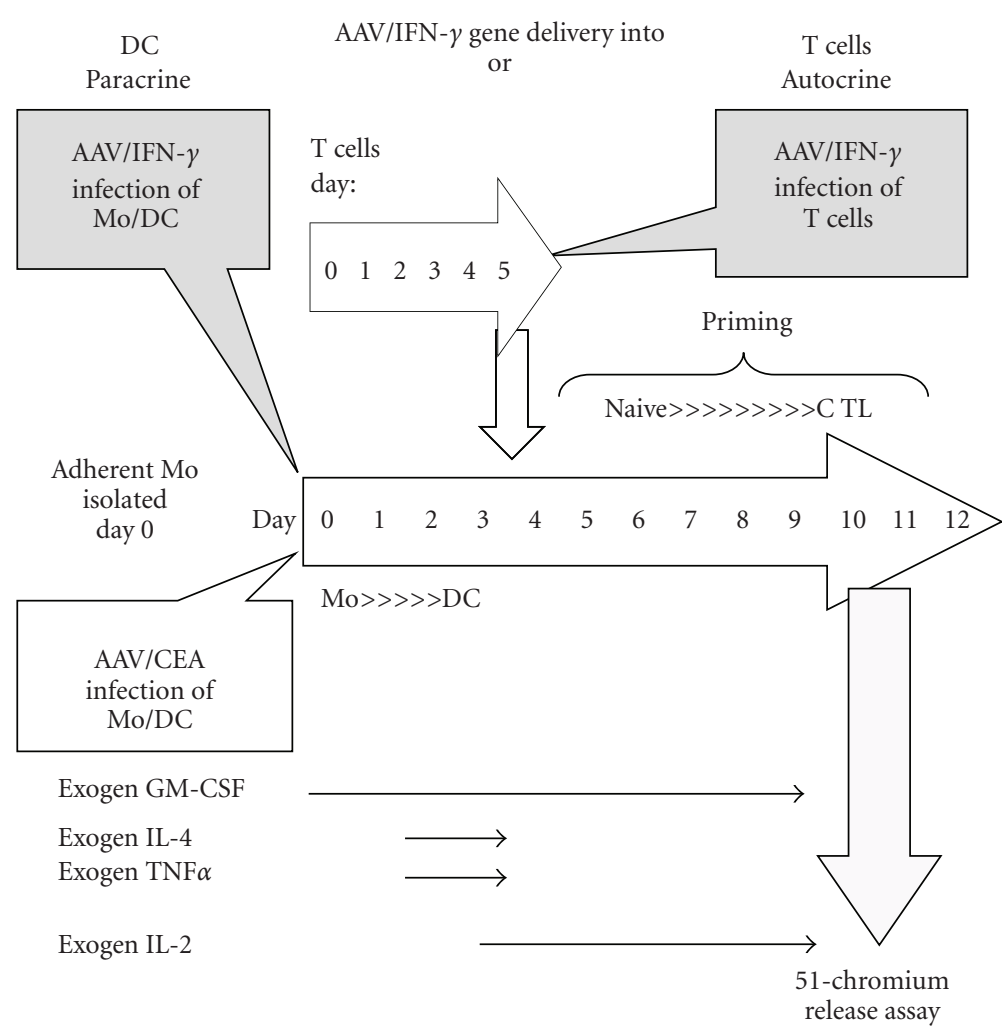

FIgURE 1: Structure of the cell treatment protocol. Shown is the temporal treatment of the Mo/DC and T cells and is self-descriptive. However, note that AAV/IFN- $\gamma$ is used to infect Mo/DC at day zero, or naive T cells just prior to coincubation with AAV/antigen-loaded DC on day 5.

PE-labeled monoclonal antibodies recognizing the following antigens, respectively: CEA, IFN- $\gamma$, and IL-2 (BD Pharmingen). Control irrelevant isotype-matched FITC- or PEconjugated monoclonal antibodies were also obtained from BD Pharmingen. A FACSCalibur flow cytometer (BectonDickinson) was used for data acquisitions. At least ten thousand events were counted for each sample.

2.8. Stimulation of Cytotoxic T Lymphocytes (CTLs) by Treated DC. At day 5-6 of DC culture the mature DCs were harvested and mixed with CD3+ T lymphocytes (ratios from $20: 1, \mathrm{~T}: \mathrm{DC}$ ) in AIM-V medium, respectively. Some T cells were untransduced while others were previously infected with AAV/IFN- $\gamma$. Mixtures were cultured in AIM-V containing IL-2 (20 IU/mL) and IL-7 $(20 \mathrm{ng} / \mathrm{mL})$. The medium and cytokines were replaced every two days. Exogenous IFN- $\gamma$ was used at $100 \mathrm{U} / \mathrm{mL}$. At 7-8 days postaddition to DC the cells were harvested and analyzed further.

2.9. FACS Analysis of DC and T Cells. After 6 days the nonadherent DCs were harvested ( $>95 \%$ viable as assessed by Trypan blue exclusion) and the cells counted and distributed. For the analysis of DC a panel of FITC- or PE-labeled monoclonal antibodies recognizing the following antigens was used: CD14, CD40 (Chemicon International), HLADR, CD80, CD8, CD86, and isotype-matched antibodies (BD Pharmingen). Stained cells were assayed by fluorescence activated cell sorting (FACS) for these CD markers according to the routine method [25]. For the analysis of activated T cells, at day 8 of the mixed cell culture the stimulated $\mathrm{T}$ cell populations were analyzed for their surface markers with immunofluorescence staining by flow cytometry. A panel of FITC- or PE-labeled monoclonal antibodies recognizing the following antigens was used: CD4, CD8, CD25, and CD69 (BD Pharmingen). At day 8 postpriming $\mathrm{T}$ cells were harvested for analysis. Intracellular staining assay was performed to analyze the expression of IFN- $\gamma$ in the T cells according to the method described above. FITC-labeled antiIFN- $\gamma$ monoclonal antibody (BD Pharmingen) was used.

2.10. Analysis of $T$ Cell Proliferation Stimulated by $r A A V-$ Infected DC. After the CD3+ T cells were mixed with the DC on day 6 , each group of mixed cells was inoculated into wells of a 96-well cell culture plate. There were $5 \times 10^{5}$ cells $(200 \mu \mathrm{l})$ in each well. After the mixed cells were cultured for 8 hours in $37^{\circ} \mathrm{C}, 5 \% \mathrm{CO}_{2},{ }^{3} \mathrm{H}$-TDR incorporation test was carried out according to the routine method [25].

2.11. Analysis of CTL Killing Activity. CTLs were generated from 3 donors. At day 14 (day 8 of T cell: DC coincubation), chromium-51 $\left({ }^{51} \mathrm{Cr}\right)$ release assay was used to analyze the killing activity of CTL elicited by AAV/CEA-transduced and control DC against the target cells as previously described [25]. Briefly, the CTL cells and ${ }^{51} \mathrm{Cr}$-labeled target cells 
TABLE 1: Surface expression of CD molecules on DC, as percentage.

\begin{tabular}{|c|c|c|c|c|c|c|}
\hline DC treatment & CD14 & CD40 & CD80 & CD83 & CD86 & HLA-DR \\
\hline Ctrl (mock) & 20.7 & 21.6 & 29.8 & 22.2 & 63.7 & 90.1 \\
\hline AAV/CEA & 14.5 & 41.3 & 62.1 & 42.6 & 88.5 & 94.5 \\
\hline $\mathrm{AAV} / \mathrm{CEA}+$ exo IFN- $\gamma$ & 16.3 & 40.0 & 60.4 & 39.9 & 86.2 & 90.3 \\
\hline $\mathrm{AAV} / \mathrm{CEA}+\mathrm{AAV} / \mathrm{IFN}-\gamma$ & 12.5 & 42.4 & 65.1 & 43.1 & 89.5 & 96.2 \\
\hline
\end{tabular}

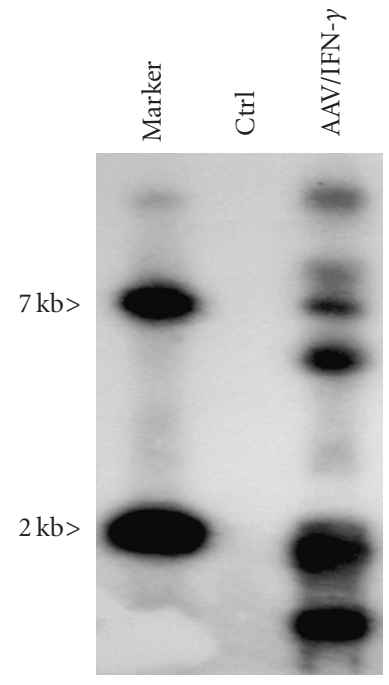

(a)

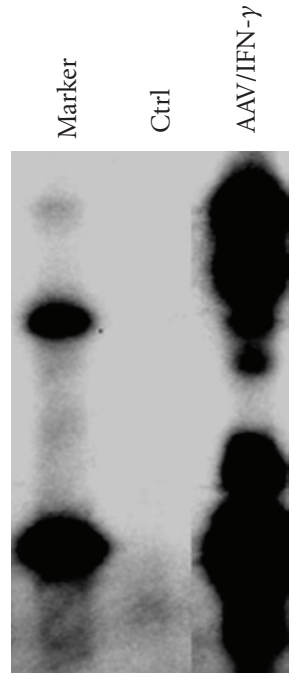

(b)
FIGURE 2: Chromosomal integration of AAV/IFN- $\gamma$ vector DNA into DC and T cells. Cells were infected as described in the Materials and Methods section and then analyzed for proviral integration by, first, PCR amplification of the vector-chromosomal junctions, followed by agarose gel electrophoresis of the PCR products, Southern blotting and probing with ${ }^{32} \mathrm{P}$ labeled vector DNA. Each band represents a separate AAV integrant within the cell population. (a) shows the results from DC. (b) shows the results from T cells.

were mixed $(20: 1)$ and incubated for 6 hours at $37^{\circ} \mathrm{C}$ with $5 \% \mathrm{CO}_{2}$. To determine MHC/HLA Class I restriction of CTL killing anti-MHC Class I monoclonal antibodies were used to block cytotoxicity. The ${ }^{51} \mathrm{Cr}$-labeled targets were preincubated with mouse antihuman MHC class I antibody (Serotec) for 1 hour before the ${ }^{51} \mathrm{Cr}$ release assay was performed. The mouse antihuman MHC class II antibody (Serotec) was also used as a control.

\section{Results}

3.1. Cloning of CEA, IFNy, and Delivery into DC and T Cells. The CEA gene, a common adenocarcinoma tumor marker, was cloned from colorectal adenocarcinoma cell line SW480 and ligated down-stream of the AAV p5 promoter within a fully gutted AAV2-based vector (d13-97). IFN- $\gamma$ was also successfully cloned into AAV in a similar manner. rAAVs were generated as described previously [24, 25] and used to transduce DC and T cells at efficiencies above $85 \%$. Our approach for transducing DC has been to infect freshly adherent peripheral blood monocytes with $\mathrm{rAAV}$, to treat these cells with GM-CSF alone for one day, and then add IL-4 to induce their differentiation into DC $[24,25,28]$. This technique has proven to be very effective in generating specific antigen-presenting DC and cytokine-expressing DC $[24,25,28]$.

3.2. rAAV Proviral Chromosomal Integration and Expression of CEA and IFN $\gamma$. One issue in the field of AAV-based gene therapy is the form of latency of the AAV proviral DNA within the transduced primary cells. In vitro tissue culture transduced cell lines often display a chromosomally integrated provirus, while in vivo transduced cells often show the latent rAAV DNA as an episomal element. To address this issue chromosomal DNA from the transduced $\mathrm{T}$ cells and DC were analyzed for integrated AAV/IFN- $\gamma$ provirus by PCR amplification of vector-chromosome junctions by using one primer directed towards the vector and another directed towards the $A l u$ I repetitive chromosomal element. Products were then agarose gel electrophoresed, Southern blotted, and ${ }^{32} \mathrm{P}-\mathrm{DNA}$ probed for vector sequences. As shown in Figures 2(a) and 2(b) this technique clearly demonstrates some level of chromosomal latency in both DC and CD3+ T cells. We have previously shown AAV/CEA chromosomal integration in DC [25].

It is important that rAAV proviruses express their transgenes. Figures 3(a) and 3(b) show that the resulting rAAV/IFN- $\gamma$ provirus does express by RT-PCR analysis, in both DC and T cells. To observe both the transduction efficiency and protein expression of IFN- $\gamma$ we carried out an intracellular staining analysis of transduced and untransduced DC and T cells. The transduction efficiency of DC by AAV/IFN- $\gamma$, as shown in Figure 4(a) (DC) and Figure 4(b) (T cells), approached $90 \%$. This agrees with our earlier studies with other transgenes, but it must be noted that $\mathrm{T}$ cells which were not transduced with AAV/IFN- $\gamma$ displayed a high background expression of $48 \%$. In any case, transduction efficiency using AAV 2 was high for both the DC and T cells.

3.3. Characterization of Transduced DC. The structure of the experimental scheme is shown in Figure 1. We infect DC with either the AAV/cytokine vector at day 0 or the T cells on day 5 just before their addition to the CEA antigen loaded DC. DCs (Mo) were always loaded by infection with AAV/CEA on day 0 . We examined the DC on day 6 , as shown in Table 1 , for surface expression of CD14, CD40, CD80, CD83, and CD86 by FACS and found that CD80, CD86, and CD83 were upregulated by rAAV infection as shown previously [29]. The addition of exogenous IFN- $\gamma$ further upregulated these 


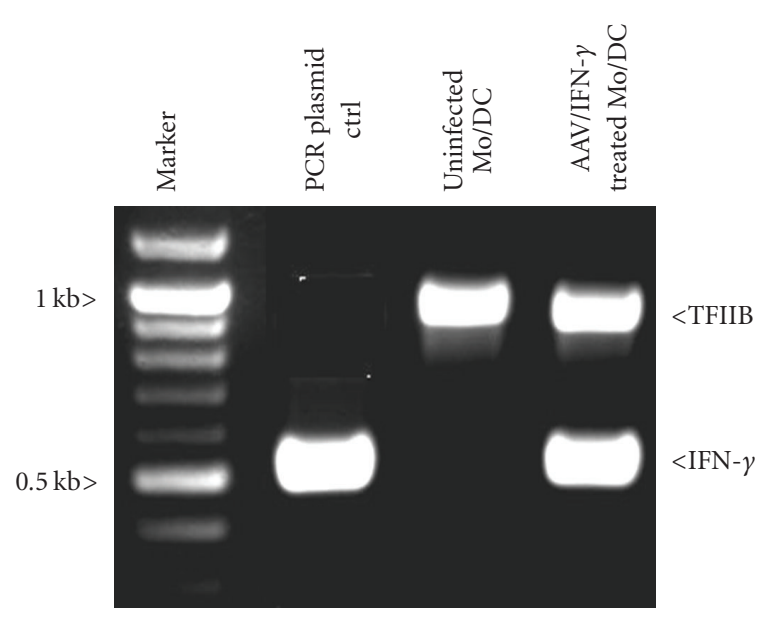

(a)

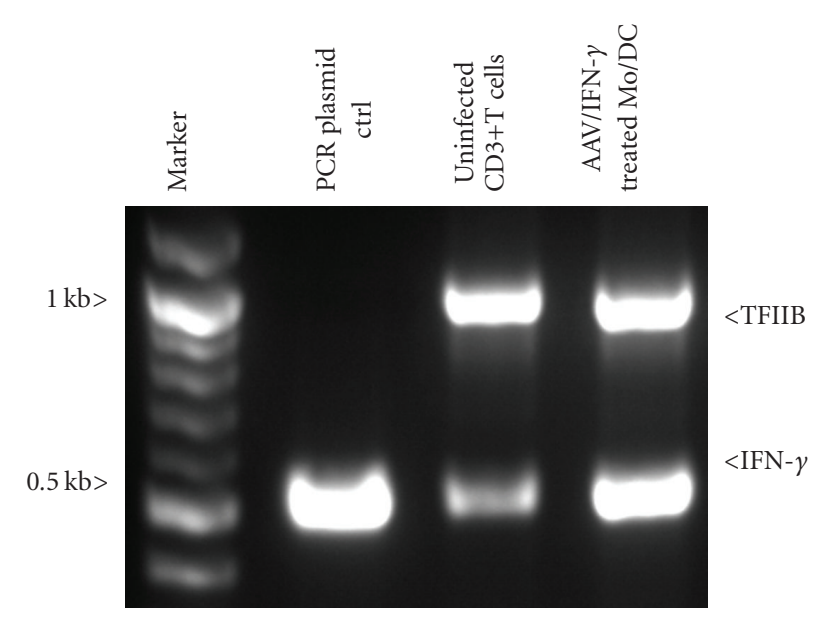

(b)

FIGURE 3: Analysis of IFN- $\gamma$ expression in transduced DC and T cells by RT-PCR. Cells were infected, mRNA isolated and analyzed by RTPCR as described in Section 2. (a) shows the results from DC. (b) shows the results from T cells. Note that both AAV/IFN- $\gamma$ transduced DC and $\mathrm{T}$ cells demonstrate IFN- $\gamma$ expression. Also note that untransduced T cells expressed some IFN- $\gamma$, but that AAV/IFN- $\gamma$ transduced T cells demonstrate higher IFN- $\gamma$ expression. This is confirmed in Figure 4.
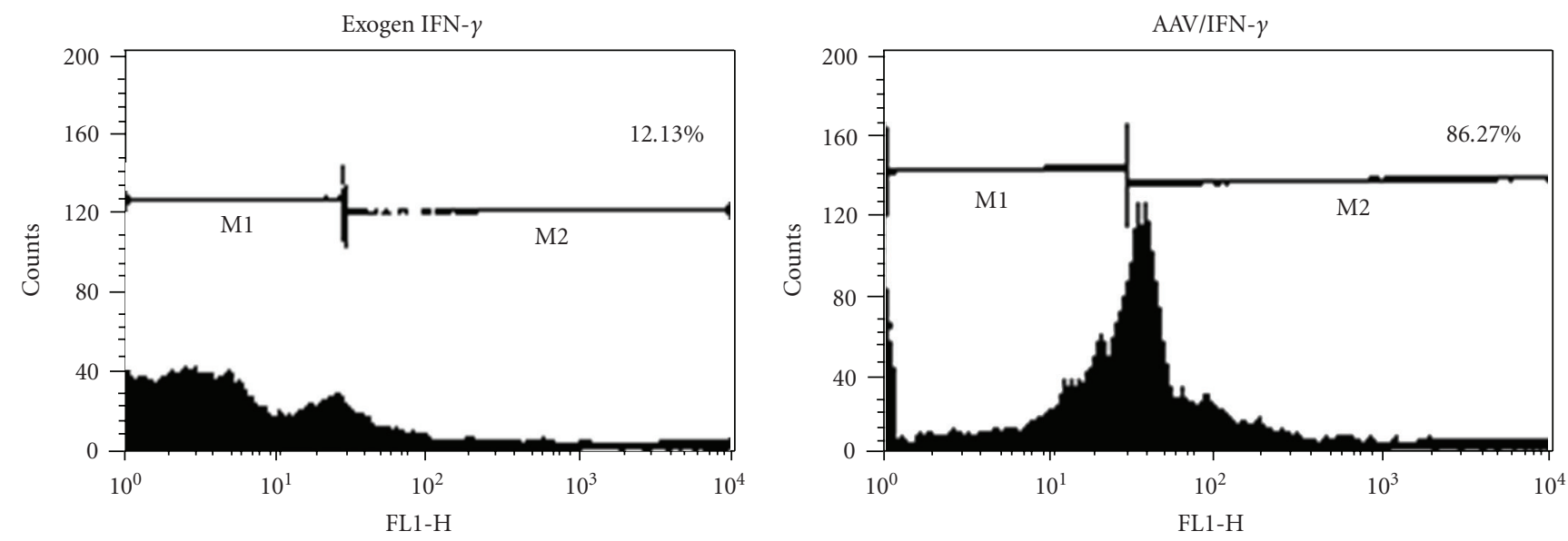

(a)
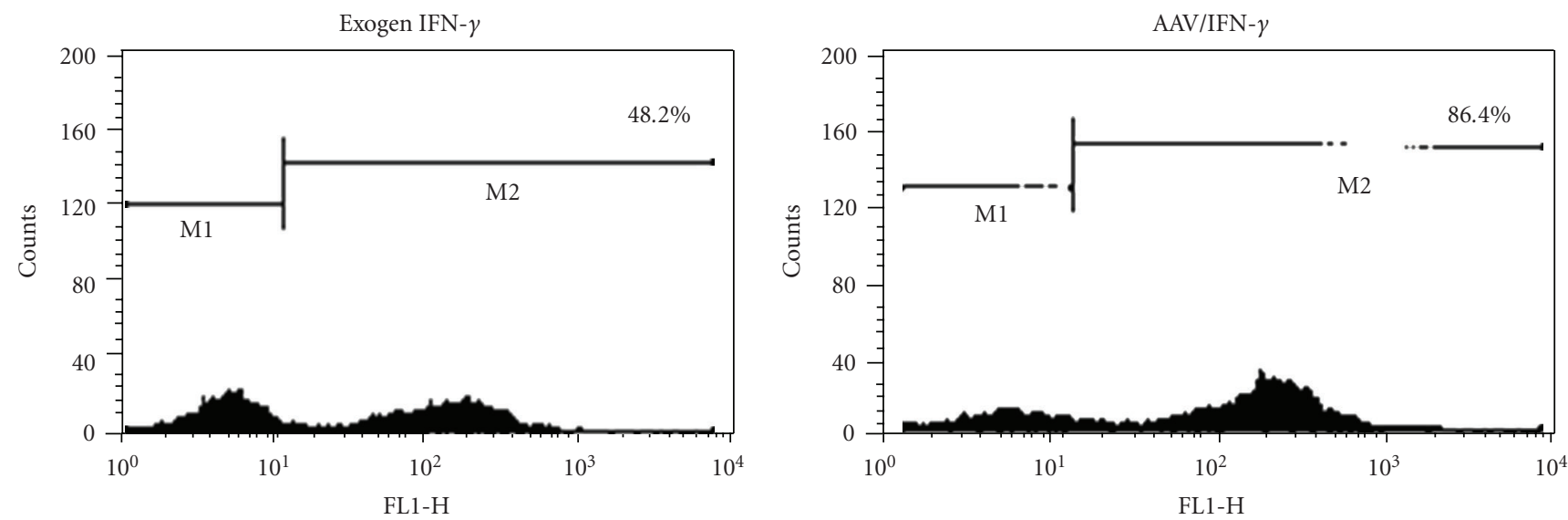

(b)

FIgure 4: Transduction efficiency of AAV delivery into DC and T cells by intracellular staining. Cells were infected as described in Section 2 and analyzed by intracellular staining for IFN- $\gamma$. (a) shows the results from DC infection. (b) shows the results from T cell infection. Note that both AAV/IFN- $\gamma$ transduced DC and T cells demonstrate high levels of IFN- $\gamma$ expression, but that T cells exhibit a signifiucant basal level of expression. 


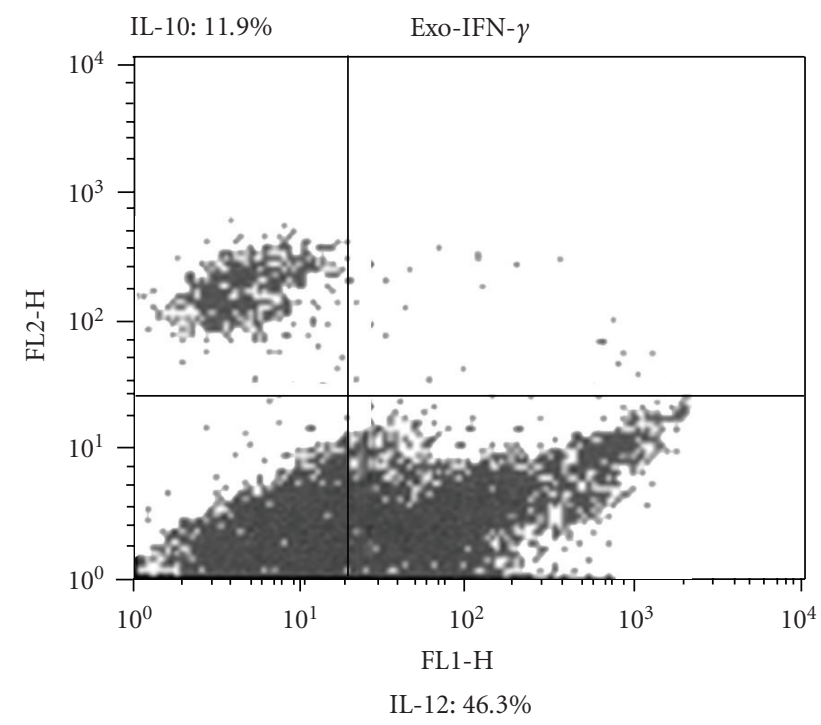

(a)

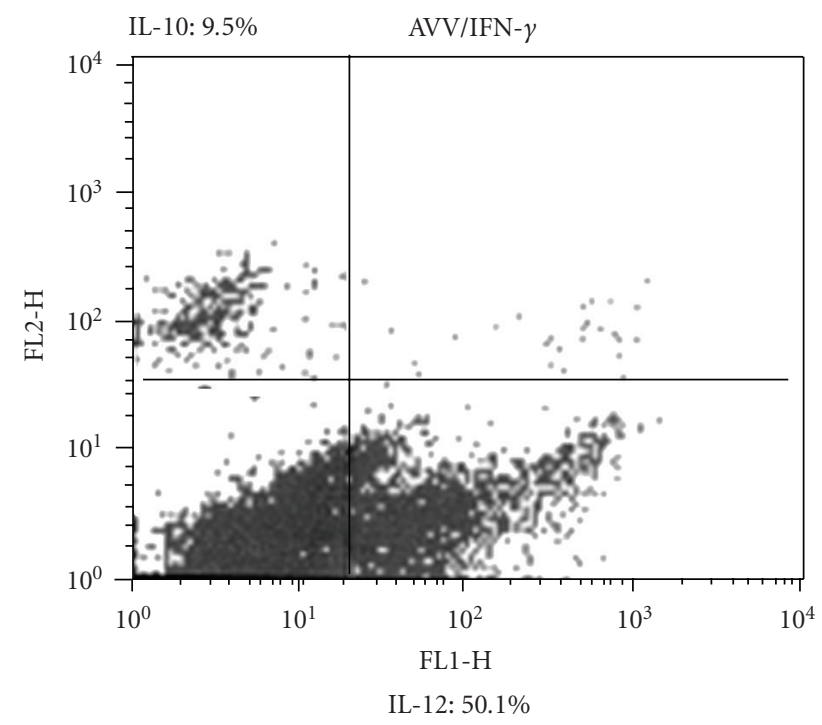

(b)

FIGURE 5: IL-12 and IL-10 expression in DC Analysis of IL-12 and IL-10 expression in DC under treatment with exogenous IFN- $\gamma$ treatment versus AAV/IFN- $\gamma$ transduction. Note that the IL-12/IL-10 ratio was slightly enhanced by AAV/IFN- $\gamma$ transduction.

markers, but the use of AAV/IFN- $\gamma$ had a more profound effect.

We further observed the resulting expression level of IL-12 and IL-10 in DC by these various treatments, as shown in Figure 5. DCs were treated with exogenous IFN$\gamma$ or AAV/IFN- $\gamma$. A high IL-12/IL-10 ratio reflects the likelihood that these DCs would stimulate a more robust Th1 CTL response; however both treatments gave a similar ratio. Secretion of IFN- $\gamma$ from DC (and T cells) was also measured by ELISA. IFN- $\gamma$ secretion from AAV/IFN$\gamma$ transduced DC, with or without AAV/CEA transduction, shown in Figure 6, was similar. Expression rose from 68 to 80 hours postinfection and then remained stable out to 92 hours. However, it is noteworthy that AAV/IFN- $\gamma$ infected T cells secrete more IFN- $\gamma$ than AAV/IFN- $\gamma$-infected DC.

\subsection{Characterization of Transduced and Stimulated T Cells.} A robust MHC/HLA Class I-restricted Th1 CTL response is most consistent with a high $\mathrm{CD} 8: \mathrm{CD} 4$ ratio. The resulting cell population stimulated by the various DC treatments was analyzed by FACS and the results listed in Table 2 upper panel. The CD8/CD4 ratio in $\mathrm{T}$ cell populations was higher when these cells were stimulated by AAVtransduced DC than with mock-treated DC (Table 2). However $\mathrm{T}$ cells derived from AAV/IFN- $\gamma$-treated DC had a slightly higher CD8/CD4 ratio, consistent these cells having slightly higher CD80, CD83, and CD86 expression (Table 1), and slightly lower IL-10 expression (Figure 5). However, the direct treatment of $\mathrm{T}$ cells by AAV/IFN$\gamma$, stimulated by AAV/CEA-loaded DC, resulted in T cell populations with the highest CD8/CD4 ratio (7.9) (Table 2 lower panel).
A robust Th1 CTL response is also consistent with a high IFN- $\gamma /$ IL-4 expression ratio. Again, the resulting $\mathrm{T}$ cells generated from any AAV-transduced DC had a higher IFN- $\gamma /$ IL-4 expression ratio than by mock treated DC (Table 2 upper panel). However, the direct treatment of T cells with AAV/IFN- $\gamma$ delivery, stimulated by AAV/CEA loaded DC, resulted in T cell populations with the highest IFN- $\gamma /$ IL-4 ratio (18.3) (Table 2 lower panel). Moreover, a robust Th1 CTL response is also consistent with a high proportion of CD69+/CD8+ T cells. Yet again, the direct treatment of $\mathrm{T}$ cells by $\mathrm{AAV} / \mathrm{IFN}-\gamma$, stimulated by AAV/CEA loaded DC, resulted in $\mathrm{T}$ cell populations with the highest percent of CD69+/CD8+ T cells (91.3\%) (Table 2 lower panel). Finally, a robust Th1 CTL would also be consistent with low CD25+/CD4+ Treg cell numbers. Again, the direct treatment of $\mathrm{T}$ cells by $\mathrm{AAV} / \mathrm{IFN} \gamma$, stimulated by AAV/CEA loaded DC, resulted in $\mathrm{T}$ cell populations with the lowest percent of CD25+/CD4+ Treg cells (17.1\%) (Table 2 lower panel). Taken together these data suggest that AAV/IFN $\gamma$ autocrine-delivery into $\mathrm{T}$ cells offers the most powerful Th1-T cell population as measured by the $\mathrm{CD} 8 / \mathrm{CD} 4$ ratio, IFN- $\gamma / \mathrm{IL}-4$ ratio, highest percentage CD69+, CD8+ cells, and lowest percent CD25+, CD4+ cells.

The generation of responder CTL involves both the proliferation of CD4+ helper T cells as well as proliferation of the CD8+ T cells themselves. To test the level of $\mathrm{T}$ cell proliferation we carried out the standard protocol for the generation of antigen-specific CTL. However, in addition to loading the DC with the antigen (AAV/CEA) we also added the delivery of AAV/IFN- $\gamma$ into DC or T cells. Proliferation of CD3 + T cells was measured by the incorporation of $3 \mathrm{H}-\mathrm{TdR}$, and the results are shown in Figure 7. It appears that the use of IFN- $\gamma$ in any form offered no advantage to 


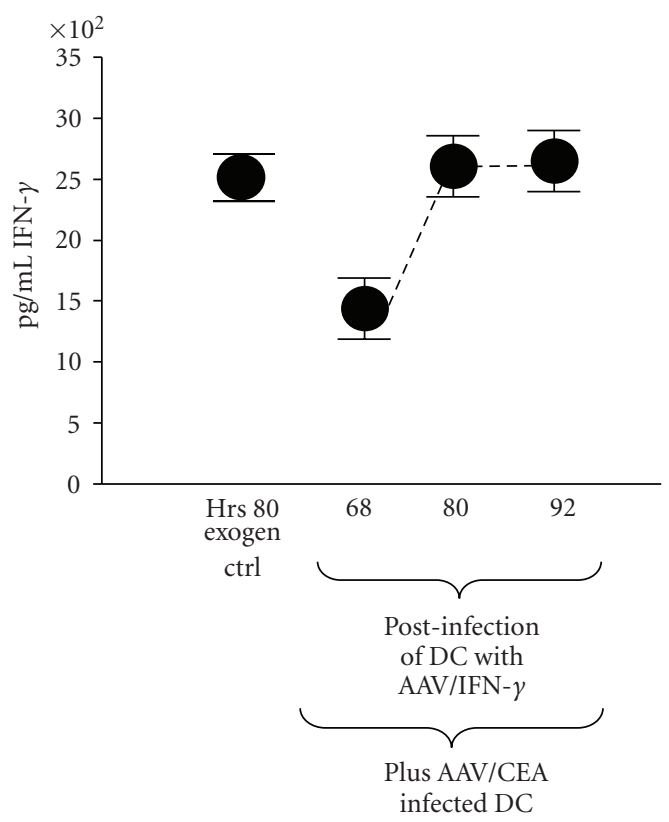

(a)

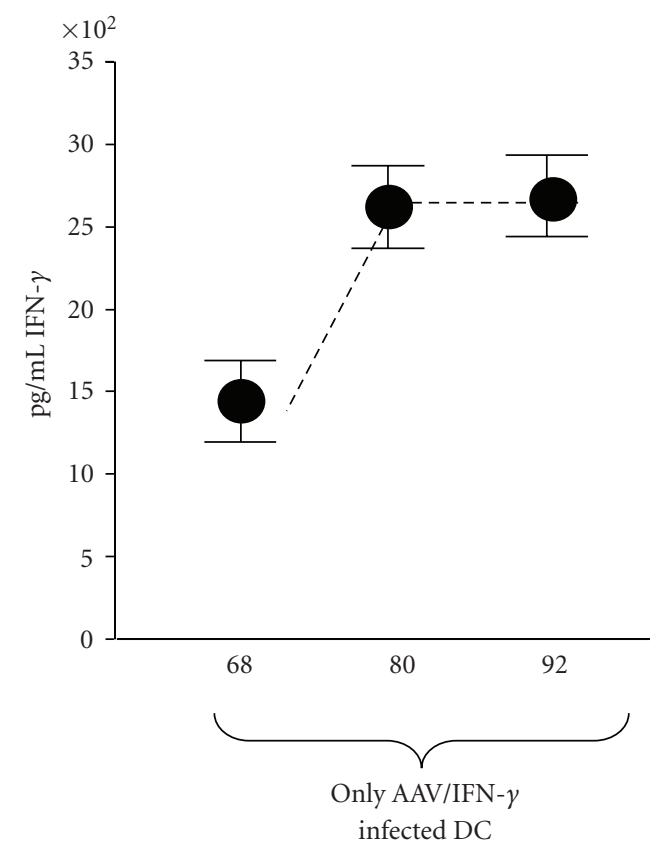

(c)

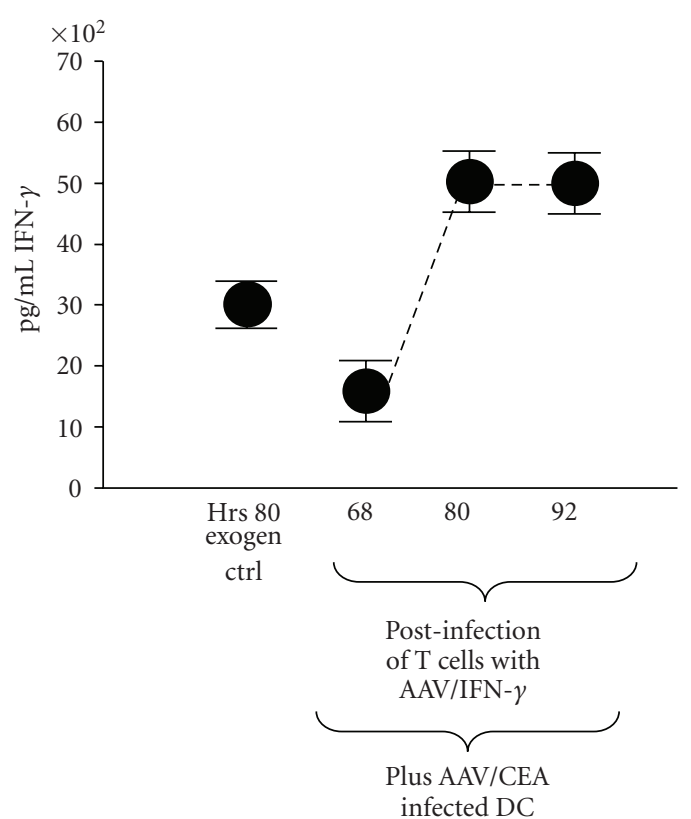

(b)

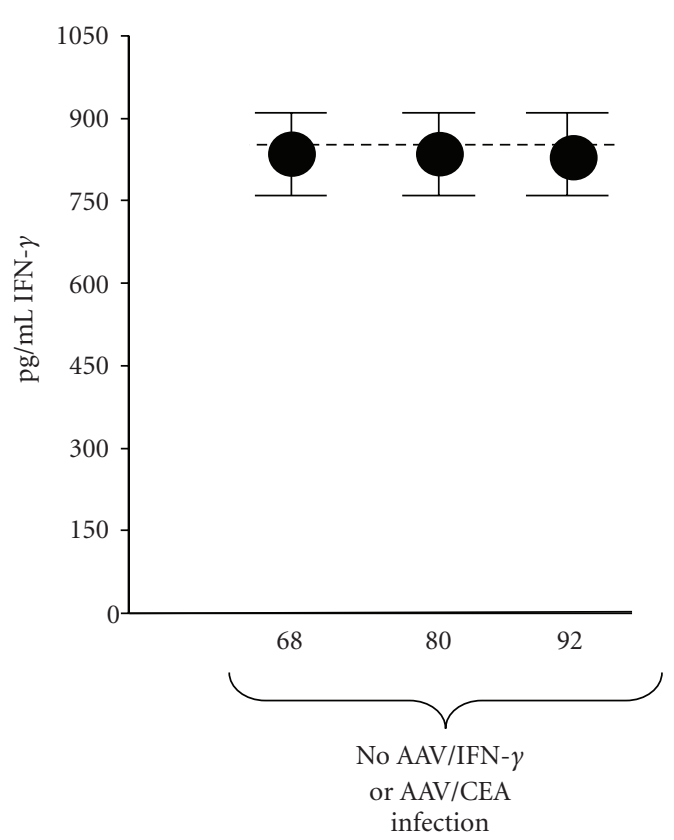

(d)

FIGURE 6: Secretion of IFN- $\gamma$ from AAV-transduced cells over time. Cells were treated as indicated and secretion of IFN- $\gamma$ was measured in the conditioned medium at the indicated time by ELISA. The conditions include AAV/IFN- $\gamma$ delivery into DC (with concurrent AAV/CEA delivery), (a); AAV/IFN- $\gamma$ delivery into T cells, (b); AAV/IFN- $\gamma$ only delivery into DC, (c); cells with no treatment, (d).

that of the stimulation of proliferation by AAV/CEA-loaded DC. Overall $\mathrm{T}$ cell proliferation is relatively equal among all treatments (Figure 7), while the $\mathrm{CD} 8 / \mathrm{CD} 4$ ratio increases (Table 2) when T cells are AAV/IFN- $\gamma$-infected. This suggests that CD8+ T cells are preferentially stimulated to proliferate.

3.5. Autocrine IFN- $\gamma$ Gene Delivery Enhances CTL Killing. Having characterized the AAV/IFN- $\gamma$ transduced DC and T cells we then assayed the resulting CTL for their ability to kill a genetically altered CEA-positive lymphoblastoid cell line (LCL) which was HLA A2-matched with blood donors. To do this we carried out the experiment depicted in Figure 1 and tested for SW480 cell target killing using the standard ${ }^{51} \mathrm{Cr}$ release assay, and the results are shown in Figure 8(a). As can be seen the highest level of CEA-directed killing results from AAV/IFN- $\gamma$ autocrine delivery into $\mathrm{T}$ cells, a $49 \%$ 
TABLE 2: Characterization T cell subsets and cytokine expression as percentages, from AAV-infected DC (top panel) and rAAV-infected T cells (bottom panel).

\begin{tabular}{|c|c|c|c|c|}
\hline DC treatment & $\mathrm{CD} 8+/ \mathrm{CD} 4$ & IFN- $\gamma /$ IL4 & $\mathrm{CD} 69+, \mathrm{CD} 8+$ & $\mathrm{CD} 25+, \mathrm{CD} 4+$ \\
\hline Ctrl (mock) & $21.6 / 51.3$ & $21.85 / 10.75$ & 27.4 & 55.6 \\
\hline $\mathrm{AAV} / \mathrm{CEA}$ & $50.3 / 22.1$ & $26.53 / 2.73$ & 61.5 & 16.2 \\
\hline $\mathrm{AAV} / \mathrm{CEA}+$ exogen IFN- $\gamma$ & $52.1 / 23.6$ & $18.84 / 2.46$ & 60.8 & 15.6 \\
\hline $\mathrm{AAV} / \mathrm{CEA}+\mathrm{AAV} / \mathrm{IFN}-\gamma$ & $56.5 / 22.5$ & $27.71 / 2.90$ & 64.7 & 14.3 \\
\hline $\mathrm{T}$ cell treatment & $\mathrm{CD} 8+/ \mathrm{CD} 4+$ & IFN- $\gamma /$ IL4 & $\mathrm{CD} 69+, \mathrm{CD} 8+$ & $\mathrm{CD} 25+, \mathrm{CD} 4+$ \\
\hline $\mathrm{AAV} / \mathrm{IFN}-\gamma$ & $84.6 / 10.7$ & $43.4 / 2.37$ & 91.3 & 17.1 \\
\hline exogen IFN- $\gamma$ & ND & $24.28 / 1.96$ & ND & ND \\
\hline Untreated T cells & $14.1 / 69.8$ & $26.53 / 2.73$ & 20.5 & 63.5 \\
\hline
\end{tabular}

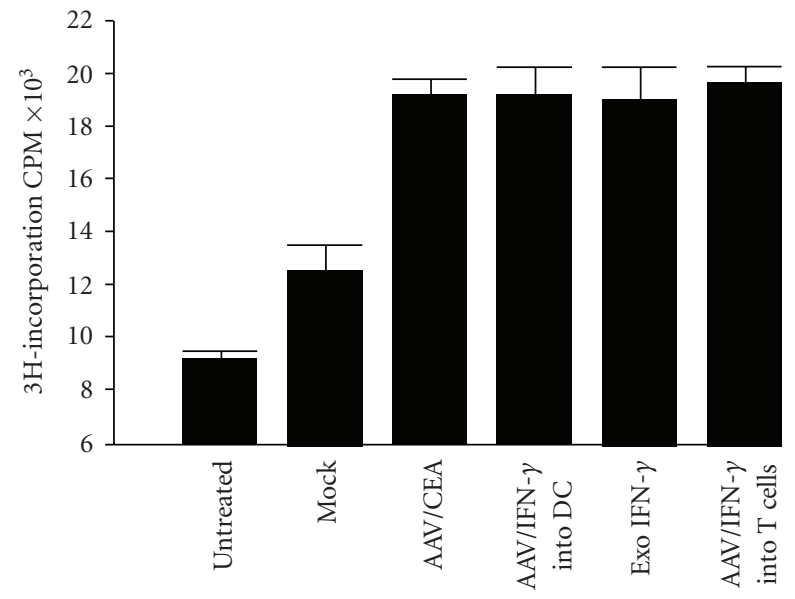

Figure 7: Proliferation of T cells. Tritium incorporation by T cells is shown under various treatments.

increase over AAV/CEA-only control. Killing was blocked by polymorphic anticlass I antibody, but not by anticlass II. The high killing that results from AAV/IFN- $\gamma$ autocrine treatment is fully consistent with the highest CD8/CD4 ratio, highest IFN- $\gamma /$ IL-4 ratio, highest percentage CD69+, CD8+ cells, and lowest percent CD25+, CD4+ cells. The higher killing may be attributed to the higher CD8+ T cell number due to higher CD8/CD4 ratio of $\mathrm{T}$ cells in AAV/IFN- $\gamma$-treated bulk $\mathrm{T}$ cell cultures versus the lower ratio generated from AAV/IFN- $\gamma$-treated DC, $84.6 \% / 10.7 \%$ versus 56.5\%/22.5\%, respectively (Table 2 ). We also utilized CEA+ LCL cells as a target and, again, AAV/IFN- $\gamma$ autocrine delivery into T cells resulted in CTL with the highest killing of CEA+ LCL, shown in Figure 8(b).

\section{Discussion}

While IFN- $\gamma$ has multiple actions which promote Th1 response [7-10], it was unclear which immune cell type should best express this cytokine. This study demonstrates that only a specific approach of IFN- $\gamma$ gene delivery, autocrine delivery, results in a CD3 $+\mathrm{T}$ cell population with higher killing ability. This was not fully anticipated as IFN- $\gamma$ affects the phenotype of both DC and $\mathrm{T}$ cells. For DC IFN stimulates significantly higher MHC class II, CD86, and slightly higher CD80 levels [30-32]. IFN- $\gamma$ also stimulates higher IL-12 expression and DC maturation [3032]. Comparing DC from IFN knockout mice and normal mice, IFN- $\gamma$ expression by DC also appears needed for the effective CD8+ T cell stimulation [33]. Normally IFN$\gamma$ expression in DC is dependent upon T-bet [34], but in this study we have circumvented this need by expressing it from the CMV promoter within the AAV backbone (AA). Moreover, NK and NKT cells are believed to be the major sources of IFN- $\gamma$ for induction of macrophage maturation [35]. This pathway has also been circumvented by AAV/IFN$\gamma$ delivery. Paracrine IFN- $\gamma$ expression by DC is believed to stimulate $\mathrm{T}$ cells to autocrine express their own IFN$\gamma$. However, IFN- $\gamma$ also has pronounced effects on $\mathrm{T}$ cells as well. While IFN- $\gamma$ inhibits the formation of Th2 cells [36], its expression directly correlates with the formation of Th1 response and CTL killing, as mentioned earlier, so much so that IFN- $\gamma$ secretion is used as a substitute for antigen specific killing assays $[12,13]$. Yet IFN- $\gamma$ appears needed for the activity of unusual CD8 $(+) \operatorname{LAP}(+)$ foxp3 $(+)$ Treg cells. Thus, there is some evidence that IFN- $\gamma$ may ultimately turn off the Th1 response that produces it [37].

Our purpose for these studies was to further analyze the mechanism of action of IFN- $\gamma$ and to optimize ex vivo generated anticancer CTL for adoptive therapies in cancer. While the adoptive transfer of ex vivo manipulated dendritic cells (DCs) appears mostly ineffective in anticancer therapies [38], the adoptive transfer of ex vivo generated anti-cancer CD8+ MHC Class I-restricted cytotoxic T lymphocytes (CTLs) seem to be a more promising treatment therapy $[39,40]$. While this study demonstrates that IFN- $\gamma$ is best delivered and expressed via the autocrine route in the generation of antigen-specific CD8(+) CTL, it should be pointed out that the basal levels of natural IFN- $\gamma$ expression also remain present and we are simply augmenting the level of IFN- $\gamma$. Thus, our interpretation of this data is that most likely the maximum effective ceiling of IFN- $\gamma$ expression and effect in DC had been reached, while the effective ceiling of IFN- $\gamma$ expression and effect in $\mathrm{T}$ cells had not been. 


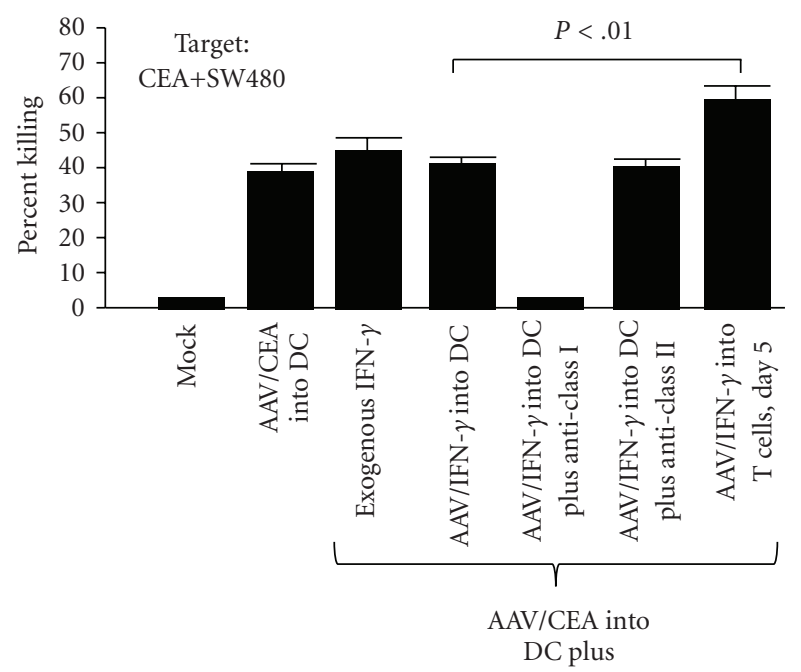

(a)

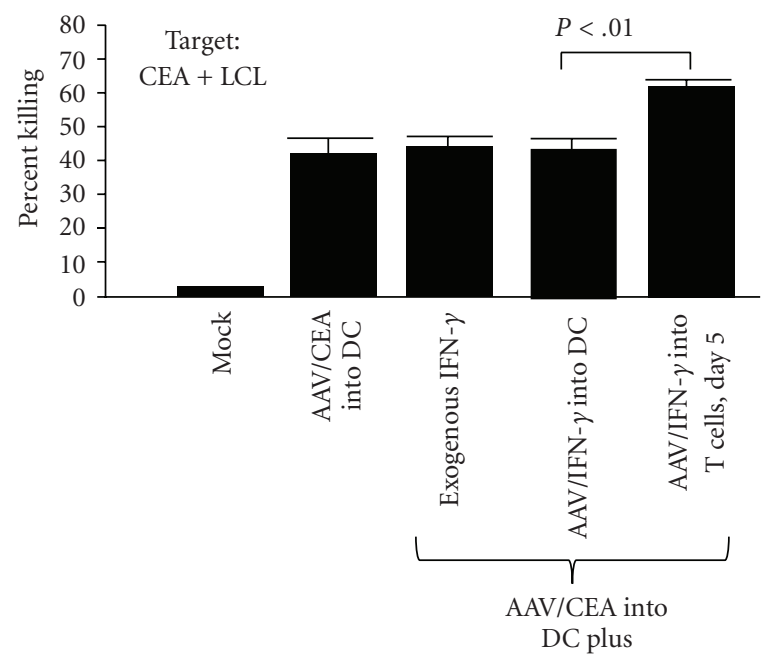

(b)

FIGURE 8: Enhanced CTL killing by IFN- $\gamma$ autocrine delivery. (a) shows CTL killing after the indicated treatment, of CEA-positive targets, SW480 cells, by standard ${ }^{51} \mathrm{Cr}$ release assay. All assays were done at a effector: target ratio of $20: 1$. Note that AAV/IFN- $\gamma$ autocrine delivery resulted in CTL with the highest killing ability. (b) shows a similar CTL killing assay using CEA+ LCL cells as the target. Note that, again, AAV/IFN- $\gamma$ autocrine delivery resulted in CTL with the highest killing ability.

Another advantage of IFN- $\gamma$ overexpression in CTL would be its known ability to upregulate MHC class I molecules, allowing for enhanced recognition of antigen expressing tumor cells [41]. Yet the practicality of the autocrine approach for certain Th1 response cytokines is questionable as the endogenous expression of certain cytokines in Th1 T cells may be problematic. The transgenic expression of IL-15 is linked with malignancy [42]. The most similar study involving IFN- $\gamma$ was by Young et al., who generated transgenic mice which overexpressed IFN- $\gamma$ in the thymus and spleen [43]. While bone-related granulomatous lesions and degeneration of cartilage was observed, there were no serious hyperproliferative cellular elements seen in the bone marrow, spleen, or lymph nodes. Thus, the adoptive transfer of IFN- $\gamma$-over expressing T cells in clinical trials may be further considered. In fact we observed no advantageous proliferation by the T cells (Figure 7). Moreover, if further work suggests that there are serious side effects of IFN- $\gamma$ overexpression in $\mathrm{T}$ cells, then the inclusion of a suicide gene within the vector, such as herpes thymidine kinase gene, would allow for the elimination of these cells when needed.

This head-to-head comparison of IFN- $y$ overexpression in DC versus $\mathrm{T}$ cells was done with the purpose of enhancing Th1 CD8(+) CTL response. However, these data also give us information as to the primary mechanism of action of IFN$\gamma$ on Th1 immune response may be through endogenous $\mathrm{T}$ cell expression. Yet further analysis is needed to determine whether it is the $\mathrm{CD} 4(+)$ or $\mathrm{CD} 8(+) \mathrm{T}$ cell which is the primary vehicle through which IFN- $\gamma$ acts. Cell ratio studies (Table 2) suggest that it is the CD8(+) T cell. Ultimately DNA microarray analysis of the T cell's transcriptome and proteomics analysis are warranted to fully understand how high IFN- $\gamma$ expression affects the cell's phenotype.

\section{Abbreviations}

AAV: Adeno-associated virus

CEA: Carcinoembryonic antigen

CD: Cluster of differentiation

DC: Dendritic cell

Foxp3: Forkhead box P3

HLA: Human leukocyte antigen

IFN: Interferon

IL: Interleukin

LCL: Lymphoblastoid cell line

MФ: Macrophage

MHC: Major histocompatibility complex

Mo: Monocytes.

\section{Acknowledgments}

This study was funded by the Fashion Footwear of New York (FFANY/QVC) through the Arkansas Breast Cancer Foundation and the Arkansas Tobacco Settlement Program. Drs. Zhang and Liu contributed equally to this study.

\section{References}

[1] M. J. Pittet, J. Grimm, C. R. Berger, et al., "In vivo imaging of T cell delivery to tumors after adoptive transfer therapy," Proceedings of the National Academy of Sciences of the United States of America, vol. 104, no. 30, pp. 12457-12461, 2007.

[2] J. R. Park, D. L. DiGiusto, M. Slovak, et al., "Adoptive transfer of chimeric antigen receptor re-directed cytolytic T lymphocyte clones in patients with neuroblastoma," Molecular Therapy, vol. 15, no. 4, pp. 825-833, 2007.

[3] A. Mackensen, N. Meidenbauer, S. Vogl, M. Laumer, J. Berger, and R. Andreesen, "Phase I study of adoptive T-cell therapy using antigen-specific $\mathrm{CD}^{+} \mathrm{T}$ cells for the treatment 
of patients with metastatic melanoma," Journal of Clinical Oncology, vol. 24, no. 31, pp. 5060-5069, 2006.

[4] A. D. Santin, P. L. Hermonat, A. Ravaggi, et al., "Development and therapeutic effect of adoptively transferred $\mathrm{T}$ cells primed by tumor lysate-pulsed autologous dendritic cells in a patient with metastatic endometrial cancer," Gynecologic and Obstetric Investigation, vol. 49, no. 3, pp. 194-203, 2000.

[5] A. D. Santin, P. L. Hermonat, A. Ravaggi, et al., "Development, characterization and distribution of adoptively transferred peripheral blood lymphocytes primed by human papillomavirus 18 E7-pulsed autologous dendritic cells in a patient with metastatic adenocarcinoma of the uterine cervix," European Journal of Gynaecological Oncology, vol. 21, no. 1, pp. 1723, 2000.

[6] A. Ribas, L. H. Butterfield, W. H. McBride, et al., "Genetic immunization for the melanoma antigen MART-1/Melan-A using recombinant adenovirus-transduced murine dendritic cells," Cancer Research, vol. 57, no. 14, pp. 2865-2869, 1997.

[7] K. Murali-Krishna, J. D. Altman, M. Suresh, D. Sourdive, A. Zajac, and R. Ahmed, "In vivo dynamics of anti-viral CD8 $\mathrm{T}$ cell responses to different epitopes: an evaluation of bystander activation in primary and secondary responses to viral infection," Advances in Experimental Medicine and Biology, vol. 452, pp. 123-142, 1998.

[8] A. H. H. van Boxel-Dezaire and G. R. Stark, "Cell typespecific signaling in response to interferon- $\gamma$," Current Topics in Microbiology and Immunology, vol. 316, pp. 119-154, 2007.

[9] J. R. Schoenborn and C. B. Wilson, "Regulation of interferon$\gamma$ during innate and adaptive immune responses," Advances in Immunology, vol. 96, pp. 41-101, 2007.

[10] A. Gattoni, A. Parlato, B. Vangieri, M. Bresciani, and R. Derna, "Interferon- $\gamma$ : biologic functions and HCV therapy (type I/II) (1 of 2 parts)," Clinica Terapeutica, vol. 157, no. 4, pp. 457-468, 2006.

[11] R. A. Corn, M. A. Aronica, F. Zhang, et al., "T cell-intrinsic requirement for $\mathrm{NF}-\kappa \mathrm{B}$ induction in postdifferentiation IFN$\gamma$ production and clonal expansion in a Th1 response," Journal of Immunology, vol. 171, no. 4, pp. 1816-1824, 2003.

[12] C. Scheibenbogen, P. Romero, L. Rivoltini, et al., "Quantitation of antigen-reactive T cells in peripheral blood by IFN $\gamma$ ELISPOT assay and chromium-release assay: a four-centre comparative trial," Journal of Immunological Methods, vol. 244, no. 1-2, pp. 81-89, 2000.

[13] F. H. Rininsland, T. Helms, R. J. Asaad, B. O. Boehm, and M. Tary-Lehmann, "Granzyme B ELISPOT assay for ex vivo measurements of T cell immunity," Journal of Immunological Methods, vol. 240, no. 1-2, pp. 143-155, 2000.

[14] J. G. Segal, N. C. Lee, Y. L. Tsung, J. A. Norton, and K. Tsung, "The role of IFN- $\gamma$ in rejection of established tumors by IL-12: source of production and target," Cancer Research, vol. 62, no. 16, pp. 4696-4703, 2002.

[15] S. Radhakrishnan, K. R. Wiehagen, V. Pulko, et al., "Induction of a Th1 response from Th2-polarized T cells by activated dendritic cells: dependence on TCR:peptide-MHC interaction, ICAM-1, IL-12, and IFN- $\gamma$," Journal of Immunology, vol. 178, no. 6, pp. 3583-3592, 2007.

[16] N. E. M. Van Emmerik, C. R. Daane, C. J. Knoop, et al., "The avidity of allospecific cytotoxic T lymphocytes (CTL) determines their cytokine production profile," Clinical and Experimental Immunology, vol. 110, no. 3, pp. 447-453, 1997.

[17] M. Hofmann, M. Radsak, G. Rechtsteiner, et al., "T cell avidity determines the level of CTL activation," European Journal of Immunology, vol. 34, no. 7, pp. 1798-1806, 2004.
[18] L. Fitzpatrick, A. P. Makrigiannis, M. Kaiser, and D. W. Hoskin, "Anti-CD3-activated killer T cells: interferon- $\gamma$ and interleukin-10 cross-regulate granzyme B expression and the induction of major histocompatibility complex-unrestricted cytotoxicity," Journal of Interferon and Cytokine Research, vol. 16, no. 7, pp. 537-546, 1996.

[19] D. S.A. Webb and T. L. Gerrard, "IFN- $\alpha$, and IFN- $\gamma$ can affect both monocytes and tumor cells to modulate monocytemediated cytotoxicity," Journal of Immunology, vol. 144, no. 9, pp. 3643-3648, 1990.

[20] J. G. Williams, G. J. Jurkovich, G. B. Hahnel, and R. V. Maier, "Macrophage priming by interferon gamma: a selective process with potentially harmful effects," Journal of Leukocyte Biology, vol. 52, no. 6, pp. 579-584, 1992.

[21] S. M. F. Akbar, K. Kajino, K. Tanimoto, K.-I. Yamamura, M. Onji, and O. Hino, "Unique features of dendritic cells in IFN- $\gamma$ transgenic mice: relevance to cancer development and therapeutic implications," Biochemical and Biophysical Research Communications, vol. 259, no. 2, pp. 294-299, 1999.

[22] T. Barnett, S. J. Goebel, M. A. Nothdurft, and J. J. Elting, "Carcinoembryonic antigen family: characterization of cDNAs coding for NCA and CEA and suggestion of nonrandom sequence variation in their conserved loop-domains," Genomics, vol. 3, no. 1, pp. 59-66, 1988.

[23] P. W. Gray, D. W. Leung, and D. Pennica, "Expression of human immune interferon cDNA in E. coli and monkey cells," Nature, vol. 295, no. 5849, pp. 503-508, 1982.

[24] Y. Liu, M. Chiriva-Internati, F. Grizzi, et al., "Rapid induction of cytotoxic T-cell response against cervical cancer cells by human papillomavirus type 16 E6 antigen gene delivery into human dendritic cells by an adeno-associated virus vector," Cancer Gene Therapy, vol. 8, no. 12, pp. 948-957, 2001.

[25] C.-X. You, Y. Liu, M. Shi, M. Cao, R.-C. Luo, and P. L. Hermonat, "Comparison of AAV/IL-7 autocrine (T cell) versus paracrine (DC) gene delivery for enhancing CTL stimulation and function," Cancer Immunology, Immunotherapy, vol. 59, no. 5, pp. 779-787, 2009.

[26] I. Ha, W. S. Lane, and D. Reinberg, "Cloning of a human gene encoding the general transcription initiation factor IIB," Nature, vol. 352, no. 6337, pp. 689-695, 1991.

[27] P. Pala, T. Hussell, and P. J. M. Openshaw, "Flow cytometric measurement of intracellular cytokines," Journal of Immunological Methods, vol. 243, no. 1-2, pp. 107-124, 2000.

[28] Y. Liu, A. D. Santin, M. Mane, et al., "Transduction and utility of the granulocyte-macrophage colony-stimulating factor gene into monocytes and dendritic cells by adenoassociated virus," Journal of Interferon and Cytokine Research, vol. 20, no. 1, pp. 21-30, 2000.

[29] M. Chiriva-Internati, Y. Liu, J. A. Weidanz, et al., "Testing recombinant adeno-associated virus-gene loading of dendritic cells for generating potent cytotoxic $\mathrm{T}$ lymphocytes against a prototype self-antigen, multiple myeloma HM1.24," Blood, vol. 102, no. 9, pp. 3100-3107, 2003.

[30] S. M. F. Akbar, K. Kajino, K. Tanimoto, K.-I. Yamamura, M. Onji, and O. Hino, "Unique features of dendritic cells in IFN- $\gamma$ transgenic mice: relevance to cancer development and therapeutic implications," Biochemical and Biophysical Research Communications, vol. 259, no. 2, pp. 294-299, 1999.

[31] S. Xu, K. Ariizumi, P. R. Bergstresser, and A. Takashima, "Cytokine-dependent regulation of growth and maturation in murine epidermal dendritic cell lines," European Journal of Immunology, vol. 25, no. 4, pp. 1018-1024, 1995. 
[32] S. M. F. Akbar, K. Inaba, and M. Onji, "Upregulation of MHC class II antigen on dendritic cells from hepatitis B virus transgenic mice by interferon- $\gamma$ : abrogation of immune response defect to a T-cell-dependent antigen," Immunology, vol. 87, no. 4, pp. 519-527, 1996.

[33] M. M. Moretto, L. M. Weiss, C. L. Combe, and I. A. Khan, "IFN- $\gamma$-producing dendritic cells are important for priming of gut intraepithelial lymphocyte response against intracellular parasitic infection," Journal of Immunology, vol. 179, no. 4, pp. 2485-2492, 2007.

[34] G. Lugo-Villarino, R. Maldonado-López, R. Possemato, C. Peñaranda, and L. H. Glimcher, "T-bet is required for optimal production of IFN- $\gamma$ and antigen-specific T cell activation by dendritic cells," Proceedings of the National Academy of Sciences of the United States of America, vol. 100, no. 13, pp. 7749-7754, 2003.

[35] T. K. Varma, C. Y. Lin, T. E. Toliver-Kinsky, and E. R. Sherwood, "Endotoxin-induced gamma interferon production: contributing cell types and key regulatory factors," Clinical and Diagnostic Laboratory Immunology, vol. 9, no. 3, pp. 530-543, 2002.

[36] A. Noble and D. M. Kemeny, "Interleukin-4 enhances interferon- $\gamma$ synthesis but inhibits development of interferon$\gamma$-producing cells," Immunology, vol. 85, no. 3, pp. 357-363, 1995.

[37] M.-L. Chen, B.-S. Yan, D. Kozoriz, and H. L. Weiner, "Novel $\mathrm{CD}^{+}$Treg suppress EAE by TGF- $\beta$ - and IFN- $\gamma$-dependent mechanisms," European Journal of Immunology, vol. 39, no. 12, pp. 3423-3435, 2009.

[38] S. Fuessel, A. Meye, M. Schmitz, et al., "Vaccination of hormone-refractory prostate cancer patients with peptide cocktail-loaded dendritic cells: results of a phase I clinical trial," Prostate, vol. 66, no. 8, pp. 811-821, 2006.

[39] S. A. Rosenberg and M. E. Dudley, "Cancer regression in patients with metastatic melanoma after the transfer of autologous antitumor lymphocytes," Proceedings of the National Academy of Sciences of the United States of America, vol. 101, supplement 2, pp. 14639-14645, 2004.

[40] S. A. Rosenberg, N. P. Restifo, J. C. Yang, R. A. Morgan, and M. E. Dudley, "Adoptive cell transfer: a clinical path to effective cancer immunotherapy," Nature Reviews Cancer, vol. 8, no. 4, pp. 299-308, 2008.

[41] D. Street, A. M. Kaufmann, A. Vaughan, et al., "Interferon$\gamma$ enhances susceptibility of cervical cancer cells to lysis by tumor-specific cytotoxic T cells," Gynecologic Oncology, vol. 65, no. 2, pp. 265-272, 1997.

[42] T. A. Fehniger, K. Suzuki, J. B. VanDeusen, M. A. Cooper, A. G. Freud, and M. A. Caligiuri, "Fatal leukemia in interleukin-15 transgenic mice," Blood Cells, Molecules, and Diseases, vol. 27, no. 1, pp. 223-230, 2001.

[43] H. A. Young, D. M. Klinman, D. A. Reynolds, et al., "Bone marrow and thymus expression of interferon- $\gamma$ results in severe B-cell lineage reduction, T-cell lineage alterations, and hematopoietic progenitor deficiencies," Blood, vol. 89, no. 2, pp. 583-595, 1997. 


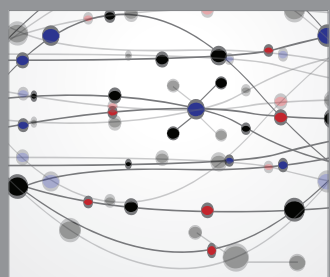

The Scientific World Journal
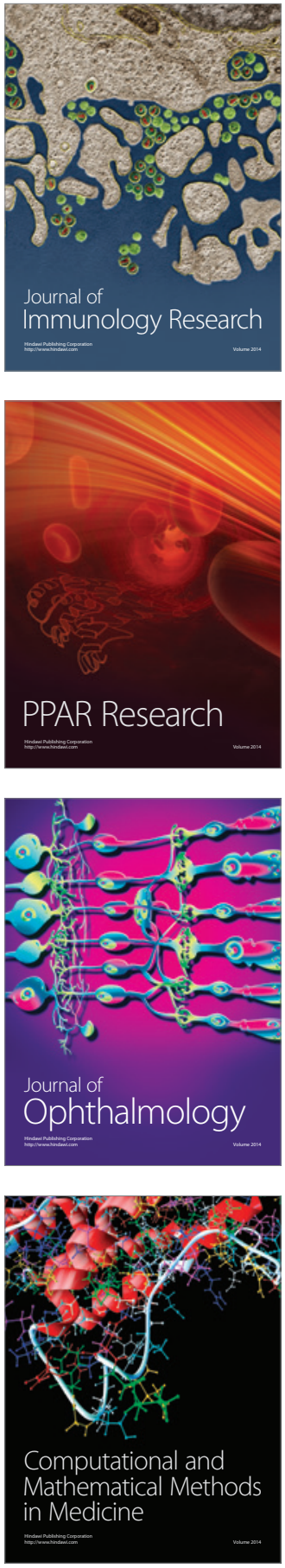

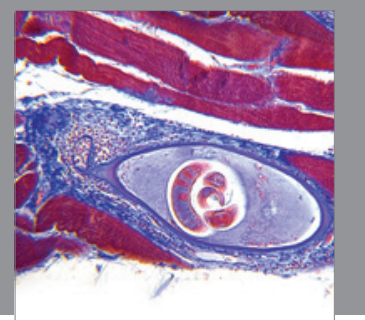

Gastroenterology

Research and Practice
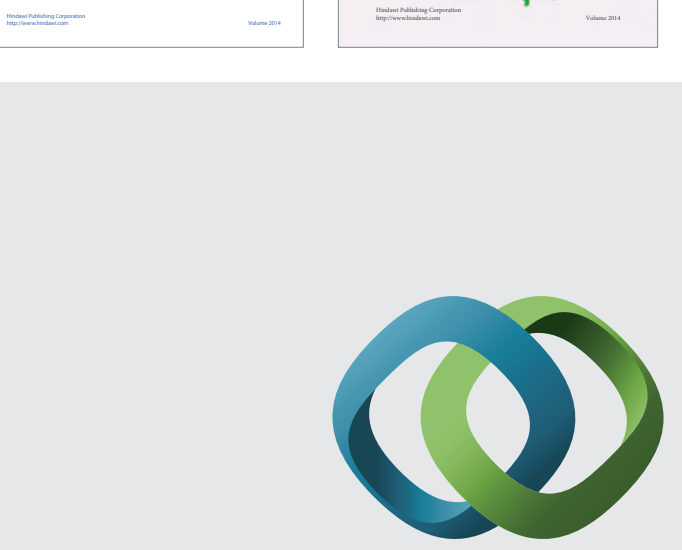

\section{Hindawi}

Submit your manuscripts at

http://www.hindawi.com
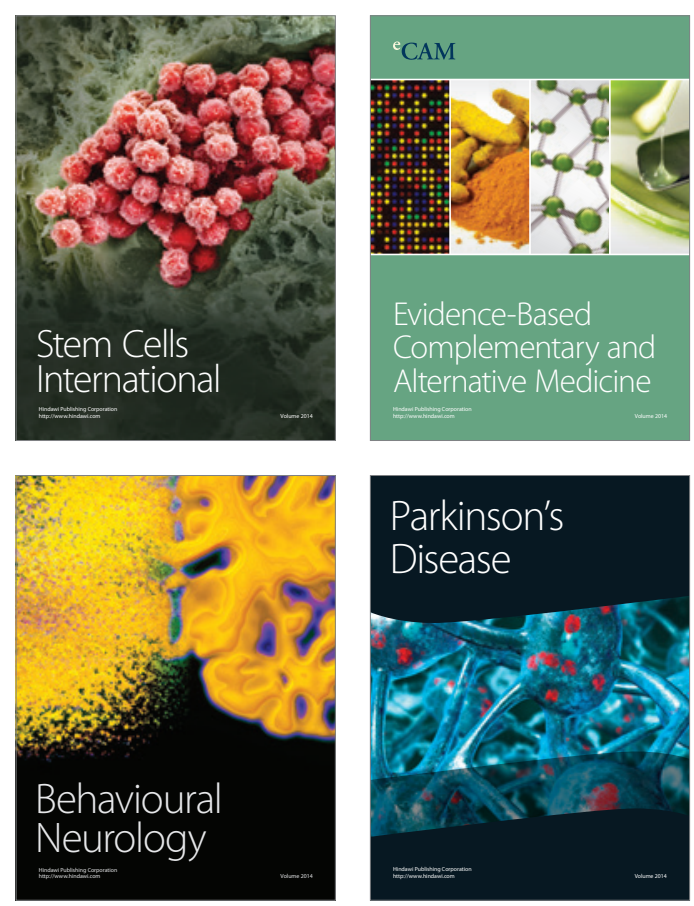

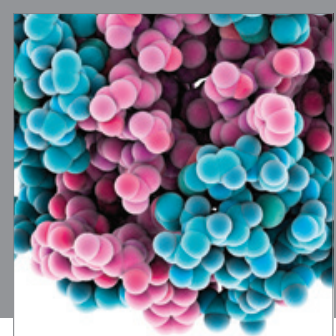

Journal of
Diabetes Research

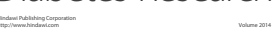

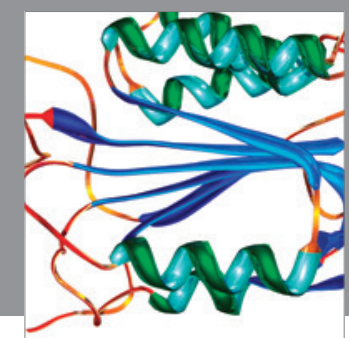

Disease Markers
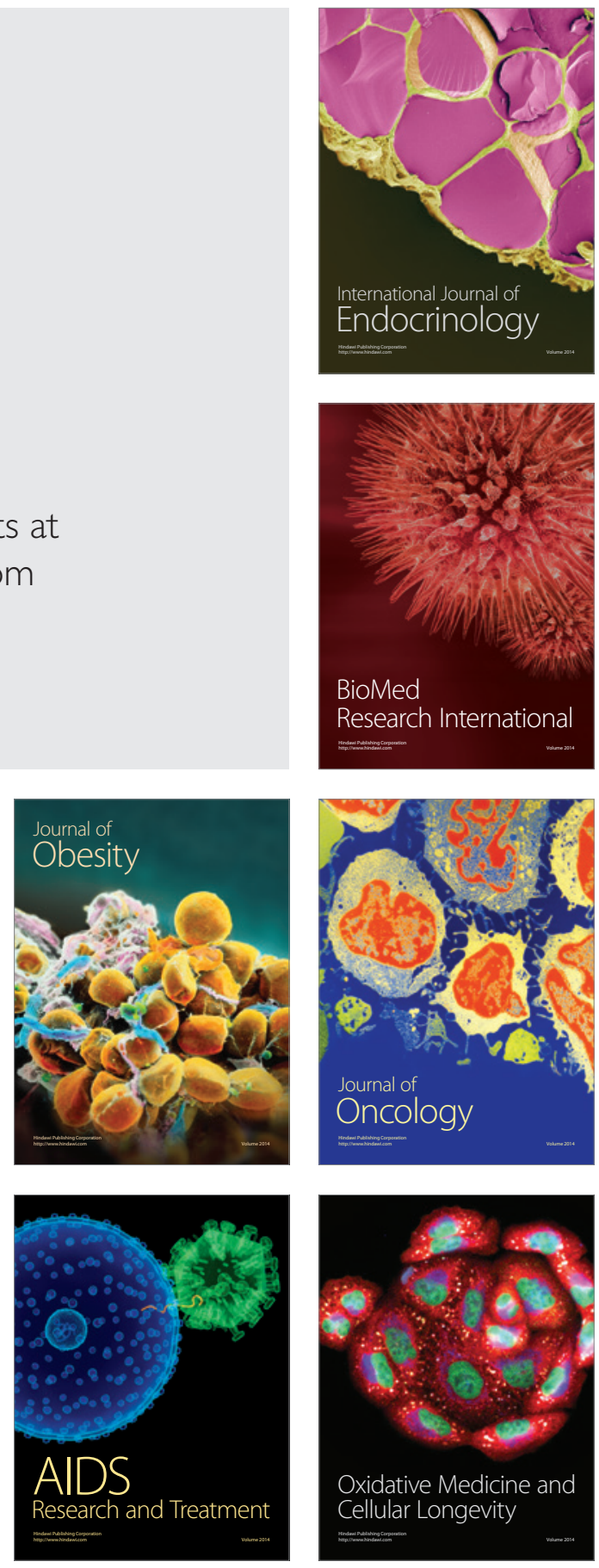